\title{
A Word from the Guest Editors
}

\section{On reconceptualizing linguistic and cultural boundaries in Canadian universities}

We write this editorial to map how we have come to see the sociolinguistic landscape of Canadian postsecondary institutions, noting the ways in which our views have been shaped by our experiences learning, teaching, and conducting research with faculty and students in several Canadian universities. From our standpoint, Canadian postsecondary institutions are experiencing greater participation of international, immigrant, and generation 1.5 students, as well as students who are first in the family to pursue higher education. We are also encountering Indigenous students who are reclaiming Indigenous languages and ways of knowing, recovering learning spaces within Canadian higher education in connection with their communities. Building on Canada's long-standing multi-ethnic society, these changes have enhanced Canadian postsecondary institutions, enriching the resources that can be drawn upon and used for teaching and learning. What were historically constructed as English or French universities entrenched in a linguistic duality of official bilingualism are now faced with rethinking the monolingual, monoglossic orientations to educational spaces situated in English- or French-dominant communities and the impact of assimilationist institutional policies (Haque, 2012; Haque \& Patrick, 2015) that have contributed to the marginalization of minoritized speakers and the systematic devastation of Indigenous peoples' languages (Ball \& McIvor, 2013; Hare, 2016; Smith, Tuck, \& Yang, 2018).

At the same time, a multilingual, heteroglossic orientation to language and learning in higher education continues to come up against traditional second/additional language pedagogies and forms of assessment. Such approaches, originating in the monolingual habitus of the field of second language acquisition (SLA), tend to measure linguistic competence according to native speaker-like norms and view the use of other languages in terms of interference or deficit. Alongside these prevailing mindsets, the political economy and hegemonic status of English in the Western academy contributes to reifying English as the most valued language of education while at the same time fuelling innovative and critical research in language education. Nonetheless, despite the wider perspectives offered in and through teaching and research in other languages and bi/multilingual education contexts, and the potential for reciprocal productive dialogue across these contexts, this work often remains in silos. That is, much of the current work reconceptualizing traditional theories and approaches to language teaching in Canada has 
been confined to the English teaching and learning context, typically with little insight into or orientation toward other languages and language teaching domains, including modern and heritage language teaching, and Indigenous language revitalization. Taken together, these tensions raise questions about how languages interact, which languages are prioritized, and whose voices construct and contribute to disciplinary knowledge and its dissemination in postsecondary settings. Such questions prompt thinking about how to include and foreground the role of language in and across disciplines, inviting engagement with linguistic and cultural diversity and understanding language as a critical resource in communication, meaning-making, and construction of knowledge in higher education and beyond.

Approaching language in higher education from a multilingual, heteroglossic stance through theories of plurilingualism (Coste, Moore, \& Zarate, 1997/2009; Lüdi \& Py, 2009) and translanguaging (García \& Li, 2014; Li, 2018) seeks to challenge and counter the dominance of English and monolingual paradigms, while also recognizing and advancing anticolonial, antiracist, and decolonizing approaches to education. With this in mind, this special issue showcases conceptual, empirical, and classroom-based work in the current Canadian postsecondary context that reflects the sociolinguistic environments of our institutions. Collectively, the contributions offer insights that can inform decisions around institutional planning as well as concrete suggestions to guide instructional practice addressing students' strengths and needs. Related work carried out in other parts of the world such as Australia and several European countries, albeit often focused on English medium instruction (EMI; e.g., Arkoudis, Baik, \& Richardson, 2012; Murray \& Nallaya, 2016; Dafouz \& Smit, 2016; Wächter \& Maiworm, 2014), has contributed to research-based understandings regarding issues faced by multilingual learners at the postsecondary level. Such work, however, is situated in sociocultural and -historical contexts that differ from the Canadian setting, the latter specifically characterized by official French-English bilingualism, multiculturalism, and Indigenous languages. Hence, this special issue represents a uniquely Canadian perspective situated in multilingual university contexts.

The themes in the special issue bring insights and raise questions that are critical to engaging with language in higher education in several interrelated ways: first, theorizing relations among language and disciplinary content, and discussing how these inform and construct practice and research; second, deepening current understandings of the interplay between enriched linguistic and cultural diversity of university students and associated teaching and learning needs; and, finally, generating insight into the diversity of strategies and approaches to curriculum, pedagogy, assessment, and policy concerning language education in postsecondary contexts. Importantly, these themes are not exclusive; rather, they interact in the porous space of the classroom, where theory and practice come together, unbounded. 


\section{Theorizing Relations among Language and Disciplinary Content}

A number of contributions in this issue demonstrate why conceptualizing language in higher education within current theories of language and bi/ multilingualism is important, namely, because how language is understood influences understandings of approaches to language teaching and learning. Viewing language learning as a complex process, the contributions to this issue evidence increasing interest in the articulation, adoption, and adaptation of theories to describe the dynamic language practices and language learning processes of university students, particularly the concepts of plurilingualism and translanguaging. Several contributions consider the significant implications of such a conceptual shift for not just English language teaching and learning, but also Indigenous and other languages.

Notably, Shin and Sterzuk open a much-needed conversation examining the tensions between discourses of internationalization and indigenization in higher education and the need to reconceptualize multilingualism in light of language-related inequalities resulting from settler colonialism and currently intersecting with contemporary capitalism. Drawing on their own professional experiences at two universities in Saskatchewan, the authors interrogate how to engage meaningfully with multilingualism, given the current efforts toward Indigenous language revitalization in a context of reconciliation alongside competing economic interests in internationalization at Canadian universities.

In another article, Burton and Rajendram highlight the unique and highly contextual ways English as a second language (ESL)/English for Academic Purposes (EAP) instructors' orientations and attitudes toward translanguaging shape their teaching practices at a large Canadian university. While much research has begun to explore what comprises a translanguaging approach, relatively few studies explore instructor beliefs about and experiences with language and how these influence their pedagogies and classroom language policies. In addressing this gap, the article sheds light on what is needed to facilitate changes in the traditional monolingual paradigms and ideologies that have tended to dominate language teaching and learning, particularly at the postsecondary level.

Shifting the focus from instructors to students, Surtees interrogates commonly used labels such as "international student," which are pervasive not only across all levels of Canadian education but are also frequently found in public discourse. Surtees argues that such labels go beyond classifying learners according to visa status, contributing to their (mis)representation as problem learners with a language deficit that requires fixing. Using discourse analysis, the author examines how the label "international" is used to index categories of linguistic, racial, or cultural otherness in interviews with her 
Japanese participants and diverse undergraduate students at a large Western Canadian university.

\section{Embracing Linguistic and Cultural Diversity}

Several contributions illustrate how greater attention has been given to the heterogeneity of linguistically diverse students and their social and academic needs, highlighting how bi/multilingualism can be addressed in language and disciplinary content teaching and learning and how language functions as a marker of identity and participation in higher education. Broadly, the contributions illustrate how faculty, students, and staff navigate changing discourses of language education as they negotiate a range of identity positions and social and academic expectations. While higher educational programs and policies often adopt a one-size-fits-all approach, some university policies are shifting toward more approaches that consider language-asresource, promoting the use of the full linguistic repertoire for disciplinary teaching and learning.

For instance, Marshall, Moore, James Lam, Ning, and Dos Santos provide a glimpse of undergraduate students' plurilingual language practices at a university in Western Canada, specifically first language (L1) Chinese speakers' use of their L1 to mediate learning across disciplines in an English-speaking environment. The authors' consideration of observational and interview data from two different courses highlights the complex negotiation students engage in as they work within and around the institutional dominance of English within a multilingual setting. According to the authors, students and instructors demonstrate a sense of ambivalence toward plurilingualism, responding to the perceived tension that arises when learning in a multilingual environment and engaging diverse language practices yet while being assessed exclusively through English.

Bringing in a program-wide perspective, Van Viegen and Russell present findings from an evaluation of a bridging program for international students at an Eastern Canadian university that examined program effectiveness and student learning outcomes. Drawing on institutional data and perceptions of faculty, students, and other stakeholders, the authors elucidate how the program understands and addresses international students' unique teaching and learning needs and goals. Aligning with related work on academic discourse socialization, these findings suggest the importance of going beyond development of students' linguistic competence, underscoring the need to focus on students' broader educational experiences to address the complex social and cultural aspects of transition to university degree studies.

Ilieva, Wallace, and Spiliotopoulos examine the academic identity constructions of applied linguists (ALs) supporting faculty working with multilingual students at a research-intensive university to better facilitate the integration of language and content. Drawing on audio-recordings of 
monthly meetings attended by 13 ALs engaged in interdisciplinary collaborations, the authors conceptualize their participants' professional identities as "cross-boundary" academics who share and build language and literacy expertise with disciplinary colleagues while simultaneously developing an enhanced understanding of those disciplinary cultures.

\section{Generating Strategies and Approaches to Curriculum, Pedagogy, Assessment, and Policy}

Within Canada, current research on English language in education tends to focus on K-12 educational contexts and, to a great extent, on integrating emerging English language users in both English and French educational settings. The contributions below highlight approaches specific to the postsecondary context, illustrating how bi/multilingualism can be engaged in learning and in developing instructional innovations for teaching language and disciplinary content in higher education. The contributions also point to the ways in which learning and teaching is both shaped and constrained by language policies as enacted in the classroom and prioritized institutional discourses. Some of these policies (e.g., assessment, admissions, funding, official languages, graduation requirements, etc.) are at odds with current conceptualizations of language and its function as a tool and resource for learning.

Admissions policy issues are brought together in MacDonald's article, which examines common language proficiency assessment standards across a large sample of Canadian universities. Focusing specifically on the International English Language Testing System (IELTS) assessment, the author draws on publicly available information about institutional requirements for international student admission. Her analysis sheds light on the kinds of issues and circumstances that drive how postsecondary institutions set language assessment criteria for admission, a process that is circumscribed by the marketization of higher education and the pressure to meet international enrolment targets. Further problematizing these concerns, MacDonald raises questions about how IELTS guidelines are interpreted in institutional policy, suggesting students may need further study and support to meet the linguistic demands of postsecondary study.

Conrad's article presents a timely discussion of proofreading practices in higher education at both the undergraduate and graduate level, elucidating how language standards are manifest in various ways, both implicit and explicit. Taking as a point of departure Editors Canada's recently released Guidelines for Ethical Editing of Student Texts, the article explores the many issues and tensions of the proofreading debate, including what editing means for students, instructors or supervisors, and proofreaders; the symbolic and economic value of academic English; and the impact especially on international students responding to university recruitment campaigns. Conrad's 
call for reflection on these issues speaks to what others have also articulated as the need for guidance on allowable support and policies that align with institutional expectations.

Illustrations of how conceptualizations of plurilingual orientations are taken up in postsecondary classrooms are showcased in two articles that attend to the integration of linguistically and culturally relevant pedagogies. Reporting on a researcher-instructor collaboration, Galante and coauthors discuss the design of pedagogic strategies and implementation of instructional tasks to promote plurilingual language practices in one course at a university-based EAP bridging program in Eastern Canada. Reflecting on the process of implementation, the authors identify several key supports for instructor collaboration and for opening instruction toward plurilingualism in EAP in higher education.

Wernicke considers how to raise awareness about and engagement in plurilingual approaches among French language teacher candidates in a required teacher education course on teaching and learning English as an additional language. The discussion takes readers through various components of the course to illustrate how initial self-reflection followed by modeling of class activities centred around school genres and grounded in a functional Hallidayan approach can offer one means of disrupting prevailing monoglossic ideologies associated with official bilingual French-English language policy.

\section{Some Final Thoughts}

Initially, this effort began in early 2017 with a colloquium on Language in the Canadian University (https://lcuweb.wordpress.com/), hosted at Simon Fraser University and the University of British Columbia, that brought together for the first time researchers, administrators, and practitioners from 17 Canadian institutions to exchange ideas and experiences. ${ }^{1}$ Participants called for further inquiry into and engagement with issues relevant to higher education policy and practice, and articulated an interest in consolidating the growing knowledge base and research expertise in Canada relating to teaching and learning language in higher education. The special issue is inspired by and a direct outcome of this collaborative interest.

Addressing theory, research, and practice, the special issue mobilizes knowledge of educational approaches to support language teaching and learning in the multilingual, multicultural university context. Whether and how such work is taken up and extended is something we are interested to learn more about from research yet to come. At the same time, we received many more articles than we were able to include in the issue, thus, we are hopeful that what we have put together constitutes only the beginning of ongoing mobilization, exchange, and dissemination of perspectives and approaches concerning language in the university context. We found that across 
Canada, such work is underway, suggesting an emerging knowledge base and expertise that, while informed by work conducted elsewhere, is, indeed, a Canadian engagement with and contribution to the interdisciplinary fields of language education.

Nonetheless, there are gaps to contend with, as evident from our initial call for contributions that sought to engage with English-language education as well as heritage and modern language learning and teaching in postsecondary contexts. Furthermore, within the current context of reconciliation in Canada, the work on this issue has made us, as special issue editors, aware of the necessity to attend not only to individual submissions but also to consider larger conversations and potential contributions that have long been absent in our field. Putting together this issue made us grapple more deeply with our growing understanding of Indigenous knowledges, and the way they are produced, read, and represented, underscoring the challenges of systemic inclusion and consistent visibility of Indigenous languages and Indigenous language revitalization in Canadian applied linguistics.

Taken together, this emergent body of work suggests an opportunity for at least another special issue, and perhaps an ongoing section in an existing Canadian journal relating specifically to the higher education context. Similarly, this expertise could be relevant for TESL/TESOL certificate programs and teacher education more broadly, to support teacher candidates and future language instructors in preservice and ongoing professional learning tailored particularly to postsecondary settings.

\author{
Saskia Van Viegen (York University) \\ Meike Wernicke (University of British Columbia) \\ Sandra Zappa-Hollman (University of British Columbia)
}

\title{
Note
}

1. The colloquium on Language in the Canadian University (LCU) was largely funded by a multi-institutional Social Sciences and Humanities Research Council (SSHRC) Connections Grant awarded to members of the LCU working group.

\section{Acknowledgement}

We would like to express our appreciation to the TESL Canada Journal editors, Farahnaz Faez and Antonella Valeo, for including this special issue, and for all their guidance and support. We also thank all authors, anonymous reviewers, and editorial assistant Michael Karas, for their invaluable contributions, as well as to all those who submitted manuscripts for consideration.

\section{References}

Arkoudis, S., Baik, C., \& Richardson, S. (2012). English language standards in higher education: From entry to exit. Camberwell: Acer Press. 
Ball, J., \& McIvor, O. (2013). Canada's big chill: Indigenous languages in education. In Language issues in comparative education (pp. 17-38). Brill Sense.

Coste, D., Moore, D., \& Zarate, G. (1997). Compétence plurilingue et pluriculturelle: Vers un cadre européen commun de référence pour l'enseignement et l'apprentissage des langues vivantes. Strasbourg: Éditions du Conseil de l'Europe.

Hare, J. (2016). "All of our responsibility": Instructor experiences with required Indigenous education courses. Canadian Journal of Native Education, 38(1), 101-120.

Dafouz, E., \& Smit, U. (2016). Towards a dynamic conceptual framework for English-Medium Education in multilingual university settings. Applied Linguistics, 37(3), 397-415.

García, O., \& Li, W. (2014). Translanguaging and education. In Translanguaging: Language, bilingualism and education (pp. 63-77). London: Palgrave Macmillan.

Gaudry, A., \& Lorenz, D. E. (2018). Decolonization for the masses? Grappling with Indigenous content requirements in the changing Canadian post-secondary environment. In L. T. Smith, E. Tuck, \& K. W. Yang (Eds.), Indigenous and decolonizing studies in education: Mapping the long view (pp. 159-174). Routledge.

Li, W. (2018). Translanguaging as a practical theory of language. Applied Linguistics 39(1), 9-30. doi:10.1093/applin/amx039

Lüdi, G., \& Py, B. (2009). To be or not to be . . a plurilingual speaker. International Journal of Multilingualism, 6(2), 154-167.

Murray, N., \& Nallaya, S. (2016) Embedding academic literacies in university programme curricula: A case study. Studies in Higher Education, 41:7, 1296-1312, DOI: 10.1080/03075079.2014.981150

Smith, L. T., Tuck, E., \& Yang, K. W. (Eds.). (2018). Indigenous and decolonizing studies in education: Mapping the long view. Routledge.

Wächter, B., \& Maiworm, F. (Eds.). (2014). English-taught programmes in European higher education: The state of play in 2014. Bonn: Lemmens Medien GmbH.

\section{Mot des rédactrices invitées}

\section{Sur la reconceptualisation des frontières linguistiques et culturelles dans les universités canadiennes}

Nous rédigeons cet éditorial afin de retracer comment nous en sommes venues à nous représenter le paysage sociolinguistique des établissements d'enseignement postsecondaire canadiens en prenant note de la manière dont notre regard a été façonné par nos expériences d'apprentissage, d'enseignement et de recherche auprès du corps professoral et des étudiantes et étudiants de plusieurs universités canadiennes. De notre point de vue, les établissements postsecondaires canadiens accueillent de plus en plus d'étudiants internationaux, qu'ils soient immigrants ou de génération 1,5, ainsi que d'étudiants qui sont le premier ou la première de leur famille à poursuivre des études supérieures. Nous rencontrons également des étudiantes et étudiants autochtones qui se réapproprient les langues et les modes autochtones d'acquisition du savoir en retrouvant des espaces d'apprentissage au niveau de l'enseignement supérieur en lien avec leurs communautés. Appuyées sur la longue tradition multiethnique de la société canadienne, ces évolutions ont renforcé les établissements postsecondaires au Canada et 
enrichi les ressources qui peuvent servir à l'enseignement et à l'apprentissage. Les universités qui, historiquement, étaient considérées comme étant soit de langue anglaise, soit de langue française, en vertu de la dualité linguistique du bilinguisme officiel se voient aujourd'hui obligées de réexaminer les orientations unilingues et monoglosses d'espaces éducatifs situés dans des communautés où l'anglais ou le français prédomine, ainsi que l'impact des politiques institutionnelles assimilationnistes (Haque, 2012; Haque et Patrick, 2015) qui ont contribué à la marginalisation des locuteurs de langues minorisées et à la dévastation systématique des langues des peuples autochtones (Ball et McIvor, 2013; Hare, 2016; Smith, Tuck, \& Yang, 2018).

Dans le même temps, l'orientation multilingue et hétéroglosse de la langue et de l'apprentissage que l'on constate au niveau de l'enseignement supérieur continue de se heurter aux pédagogies linguistiques et aux formes d'évaluation traditionnelles en matière d'apprentissage d'une langue seconde ou complémentaire. Remontant à l'habitus monolingue du domaine de l'acquisition d'une langue seconde (ALS), de telles approches ont tendance à mesurer la compétence linguistique à l'aune de normes applicables aux locuteurs natifs et à considérer l'utilisation d'autres langues comme une interférence ou un déficit. S'ajoutant à ces façons de penser prédominantes, l'économie politique et le statut hégémonique de l'anglais dans l'univers académique occidental contribuent à en faire la langue d'enseignement de prédilection tout en alimentant des recherches innovantes et critiques dans le domaine de l'enseignement des langues. Toutefois, en dépit des perspectives élargies qui sont offertes dans et par l'enseignement et la recherche dans d'autres langues et dans des contextes éducatifs bilingues et multilingues, et malgré les possibilités de dialogue réciproque productif entre ces contextes, ces travaux restent souvent en silos. Plus précisément, une bonne partie des travaux actuels de reconceptualisation des théories et des approches liées à l'enseignement des langues au Canada ont été confinés au contexte de l'enseignement et de l'apprentissage de l'anglais, et ce, typiquement, avec peu de compréhension et d'intérêt pour d'autres langues ou d'autres domaines de l'enseignement des langues, y compris celui des langues modernes et patrimoniales et la revitalisation des langues autochtones. Considérées dans leur ensemble, ces tensions soulèvent des questions sur la façon dont les langues interagissent, sur le choix des langues à privilégier et sur l'origine des voix qui construisent et enrichissent la connaissance disciplinaire et sa dissémination en milieu postsecondaire. Ces enjeux proposent une réflexion sur la façon d'inclure et de mettre en valeur le rôle de la langue à l'intérieur de chaque discipline et entre elles, et ils encouragent l'accueil de la diversité linguistique et culturelle ainsi qu'une compréhension de la langue comme étant une ressource d'une importance primordiale pour la communication, la création de sens et la construction du savoir dans l'enseignement supérieur et au delà. 
L'approche de la langue sous un angle multilingue et hétéroglosse à la lumière des théories du plurilinguisme (Coste, Moore, \& Zarate, 1997/2009; Lüdi \& Py, 2009) et du translangagisme (García \& Li, 2014; Li, 2018) dans l'enseignement supérieur vise à contester et à contrer la dominance de l'anglais et des paradigmes monolingues tout en reconnaissant et en faisant progresser des approches éducatives anticoloniales, antiracistes, et décolonisatrices. Dans cette optique, ce numéro spécial propose des travaux conceptuels, empiriques et basés sur des expériences qui se déroulent actuellement dans les salles de classe dans le contexte de l'enseignement postsecondaire au Canada et qui reflètent les environnements sociolinguistiques de nos établissements. Collectivement, ces contributions fournissent un aperçu susceptible d'éclairer les décisions dans le cadre de la planification institutionnelle en plus de faire des suggestions concrètes pour l'adoption de pratiques pédagogiques qui tiennent compte des forces et des besoins des étudiants. Bien qu'ils portent souvent sur l'anglais comme vecteur d'enseignement (EMI; par ex., Arkoudis, Baik, \& Richardson, 2012; Murray \& Nallaya, 2016; Dafouz \& Smit, 2016; Wächter \& Maiworm, 2014), certains travaux connexes réalisés dans d'autres parties du monde comme l'Australie et plusieurs pays européens ont contribue à une compréhension fondée sur la recherche des problèmes auxquels sont confrontés les apprenantes et apprenants multilingues au niveau postsecondaire. Ces travaux, toutefois, s'inscrivent dans des contextes socioculturels et sociohistoriques qui diffèrent du cadre canadien, lequel se caractérise spécifiquement par le bilinguisme anglais-français officiel, le multiculturalisme, et la présence de langues autochtones. Le présent numéro spécial offre donc une perspective distinctement canadienne à partir de contextes universitaires multilingues.

Les thèmes abordés dans ce numéro spécial apportent des éclairages et soulèvent des questions qui revêtent une importance primordiale pour le rapport aux langues dans l'enseignement supérieur, et ce, de plusieurs manières interdépendantes: premièrement, une représentation théorique des relations entre la langue et le contenu disciplinaire ainsi qu'une discussion de la façon dont ces relations alimentent et construisent la pratique et la recherche; deuxièmement, un approfondissement des compréhensions actuelles de l'interaction entre l'enrichissement de la diversité linguistique et culturelle des étudiants et les besoins d'enseignement et d'apprentissage qui lui sont associés; et enfin l'apport d'un éclairage sur la diversité des stratégies et des approches relatives au curriculum, à la pédagogie, à l'évaluation, et aux politiques relativement à l'enseignement des langues dans des contextes postsecondaires. Chose importante, ces thèmes ne sont pas exclusifs les uns des autres, mais interagissent plutôt dans l'espace poreux de la salle de classe, où théorie et pratique se complètent librement. 


\section{Représentation théorique des relations entre la langue et le contenu disciplinaire}

Certains articles du présent numéro démontrent pourquoi il est important de concevoir le rôle de la langue dans l'enseignement supérieur à la lumière des théories actuelles sur la langue et le biculturalisme ou le multiculturalisme, la raison en étant que la façon de comprendre le langage affecte la compréhension des approches relatives à l'enseignement et à l'apprentissage des langues. Considérant l'apprentissage linguistique comme un processus complexe, les auteurs des articles du présent numéro font état d'un accroissement d'intérêt pour l'articulation, l'adoption, et l'adaptation de théories afin de décrire les pratiques linguistiques et les processus d'apprentissage dynamiques des étudiantes et étudiants universitaires, particulièrement les concepts du plurilinguisme et du translangagisme. Plusieurs articles évoquent les implications significatives d'une telle évolution conceptuelle, et ce, non seulement pour l'enseignement et l'apprentissage de l'anglais, mais aussi pour ceux des langues autochtones et d'autres langues.

Notablement, Shin et Sterzuk entament une conversation indispensable en examinant les tensions qui existent entre les discours portant sur l'internationalisation et sur le besoin de reconcevoir le multilinguisme à la lumière des inégalités liées à la langue, lesquelles résultent du colonialisme de peuplement et sont aujourd'hui encouragées par le capitalisme contemporain. En s'appuyant sur leurs propres expériences professionnelles dans deux universités différentes de la Saskatchewan, les auteures de cet article s'interrogent sur la manière de s'engager de façon significative dans le multilinguisme compte tenu des efforts qui sont déployés actuellement pour revitaliser les langues autochtones dans un contexte de réconciliation sur un fond de concurrence d'intérêts économiques et d'internationalisation dans les universités canadiennes.

Dans un autre article, Burton et Rajendram soulignent les manières particulières et hautement contextuelles dont les orientations et les attitudes des professeurs d'anglais lange seconde (ESL) et d'anglais académique (EAP) face au translangagisme en façonnent les pratiques d'enseignement dans une université de l'Ouest canadien. Même si de nombreuses recherches ont commencé à explorer le contenu de l'approche du translangagisme, relativement peu d'études explorent l'enjeu des croyances et des expériences linguistiques des professeurs ou celui de la façon dont elles affectent leur pédagogie et leurs politiques relativement à la langue utilisée en classe. En se penchant sur cette lacune, les auteurs de cet article font ressortir ce qu'il faudra pour faciliter les changements au sein des paradigmes et des idéologies monolingues traditionnelles qui ont eu tendance à dominer l'enseignement et l'apprentissage des langues jusqu'ici, particulièrement au niveau postsecondaire.

Mettant l'accent sur les étudiants plutôt que sur les professeurs, Surtees s'interroge sur l'utilisation généralisée d'étiquettes comme "étudiants 
internationaux » qui envahissent non seulement les établissements canadiens d'enseignement supérieur à tous les niveaux, mais que l'on retrouve fréquemment aussi dans le discours public. Surtees soutient que de telles étiquettes reviennent à classer les apprenants en fonction de l'état de leur demande de citoyenneté, ce qui contribue à les présenter (faussement) comme des étudiants qui ont des problèmes d'apprentissage et dont le déficit linguistique doit être comblé. Au moyen d'une analyse du discours, l'auteure examine comment l'étiquette «international » est utilisée pour indexer les catégories d'altérité linguistique, raciale, ou culturelle dans le cadre d'entrevues avec des participants japonais et une variété d'étudiants de premier cycle dans une grande université de l'Ouest du Canada.

\section{Accueillir la diversité linguistique et culturelle}

Plusieurs articles soulignent le fait qu'on accorde aujourd'hui davantage d'attention à l'hétérogénéité des étudiants de langue différente ainsi qu'à leurs besoins sociaux et académiques, et ce, en expliquant comment le bilinguisme et le multilinguisme peuvent être pris en compte dans l'enseignement et l'apprentissage des contenus disciplinaires, et comment la langue fonctionne comme un marqueur d'identité et de participation dans l'enseignement supérieur. En gros, les articles illustrent la façon dont le corps professoral, les étudiants, et le personnel s'adaptent à l'évolution du discours de l'enseignement des langues en négociant toute une gamme de positions identitaires et d'attentes sociales et académiques. Alors que les programmes et les politiques de l'enseignement supérieur adoptent fréquemment des approches uniformes, certaines politiques universitaires s'orientent vers des approches plus globales qui considèrent la langue comme une ressource et recourent à la totalité du répertoire linguistique pour l'enseignement et l'apprentissage des disciplines.

Marshall, Moore, James Lam, Ning, et Dos Santos, par exemple, présentent un aperçu des pratiques linguistiques plurilingues des étudiantes et étudiants de premier cycle d'une université de l'Ouest du Canada, et plus précisément de la façon dont des locuteurs de langue maternelle chinoise utilisent leur première langue (L1) comme un instrument de médiation de l'apprentissage interdisciplinaire dans un environnement anglophone. Les données d'observation et d'entrevues recueillies par les auteurs au sujet de deux cours différents mettent en lumière la négociation complexe à laquelle les étudiants s'adonnent pour évoluer à l'intérieur et autour de la dominance institutionnelle de l'anglais dans un contexte bilingue. Selon les auteurs, les étudiants font preuve d'ambivalence envers le plurilinguisme en réaction contre les tensions qu'ils perçoivent dans un environnement d'apprentissage multilingue où ils s'adonnent à des pratiques linguistiques diversifiées, mais dans le cadre duquel leur évaluation se fait exclusivement sous l'angle de l'anglais. 
Plus générale, l'étude de Van Viegen et Russell présente les conclusions de l'évaluation d'un programme de transition offert aux étudiants internationaux d'une université de l'Est du Canada, évaluation qui porte sur l'efficacité de ce programme et sur les résultats d'apprentissage des étudiants. S'appuyant sur des données institutionnelles et sur les perceptions du corps professoral, des étudiants et d'autres intervenants, les auteurs décrivent comment le programme comprend et prend en compte les besoins et les objectifs particuliers d'enseignement et d'apprentissage des étudiants internationaux. S'alignant sur des travaux connexes dans le domaine de la socialisation du discours académique, ces constatations suggèrent qu'il est important d'aller au delà des compétences linguistiques des étudiants et soulignent le besoin de considérer l'ensemble de leurs expériences d'apprentissage pour composer avec la complexité des aspects sociaux et culturels complexes de leur transition vers des études menant à un grade universitaire.

Ilieva, Wallace, et Spiliotopoulos examinent les constructions d'identité académique de linguistes en linguistique appliquée (ALs) collaborant avec le corps professoral et travaillant auprès d'étudiants multilingues dans une université centrée sur la recherche en vue de faciliter l'intégration de la langue et du contenu. S'appuyant sur des enregistrements sonores de réunions mensuelles auxquelles assistaient 13 linguistes en linguistique appliquée participant à des collaborations interdisciplinaires, les auteures présentent les professionnels participants comme des universitaires « transfrontaliers » qui partagent et construisent des compétences de langue et de littératie avec des collègues de diverses disciplines en développant une compréhension enrichie de ces cultures disciplinaires.

\section{Création de stratégies et d'approches face au curriculum, à la pédagogie, à l'évaluation et aux politiques}

À l'intérieur du Canada, les recherches actuelles sur la place de l'anglais dans l'enseignement ont tendance à se concentrer sur des contextes éducatifs allant de la maternelle à la $12^{\mathrm{e}}$ année et, dans une large mesure, à concerner l'intégration de locuteurs anglophones émergents dans des contextes éducatifs anglophones ou francophones. Les articles ci-dessous mettent en relief des approches spécifiques au contexte postsecondaire en illustrant la façon dont le bilinguisme et le multilinguisme peuvent être mis à contribution dans l'apprentissage et le développement d'innovations pédagogiques à apporter à l'enseignement des langues et des contenus disciplinaires dans l'enseignement supérieur. Les articles évoquent également les façons dont l'apprentissage et l'enseignement sont façonnés et réduits tant par les politiques linguistiques observées en classe que par les discours institutionnels privilégiés. Certaines de ces politiques (par ex., évaluation, admissions, financement, langues officielles, exigences relatives à l'obtention d'un diplôme, 
etc.) sont incompatibles avec les conceptions actuelles de la langue et de sa fonction comme outil et ressource d'apprentissage.

L'article de MacDonald regroupe les enjeux de politique d'admission en examinant des normes d'évaluation de compétences linguistiques qui sont appliquées par un large éventail d'universités canadiennes. Se concentrant spécifiquement sur le Système international de tests de la langue anglaise (IELTS), l'auteure s'appuie sur des informations accessibles au public sur les exigences des établissements pour l'admission d'étudiants étrangers. Son analyse jette un éclairage sur les genres de questions et de circonstances qui régissent la façon dont les établissements postsecondaires établissent leurs critères d'évaluation des candidates et candidats à l'admission dans un encadrement de commercialisation de l'enseignement supérieur et de pressions exercées par une volonté d'atteindre les objectifs d'inscription d'étudiants internationaux. Jugeant ces préoccupations très problématiques, MacDonald soulève des questions sur la façon dont les lignes directrices IELTS sont interprétées dans les politiques des établissements, ce qui suggère que les étudiants pourraient avoir besoin de davantage d'études et de soutien pour répondre aux exigences linguistiques des études postsecondaires.

L'article de Conrad présente une discussion opportune des pratiques de correction de texte des étudiants de premier et de second cycles de l'enseignement supérieur en décrivant les manières implicites et explicites dont les normes linguistiques se manifestent. En prenant comme point de départ un document de publication récente de Réviseurs Canada intitulé Guidelines for Ethical Editing of Student Texts, l'article explore les nombreuses questions et tensions inhérentes au débat sur la révision des textes, y compris ce que les étudiants, les professeurs ou superviseurs, et les correcteurs entendent par " révision »; la valeur symbolique et économique de l'anglais académique; et par-dessus tout l'impact de la révision sur les étudiants internationaux qui répondent aux campagnes de recrutement des universités. Le besoin de réflexion invoqué par Conrad fait écho aux besoins d'orientation que d'autres ont déjà exprimés relativement à l'ampleur du soutien permissible et à l'élaboration de politiques qui s'alignent sur les attentes des établissements.

Des illustrations de la façon dont les conceptualisations d'orientations plurilingues sont adoptées dans les salles de classe postsecondaires sont présentées dans deux articles qui portent sur l'intégration de pédagogies linguistiquement et culturellement pertinentes. Dans leur compte rendu d'une collaboration entre chercheurs et professeurs, Galante et ses coauteurs discutent de la conception de stratégies pédagogiques et de la mise en œuvre de tâches pédagogiques capables de promouvoir les pratiques linguistiques plurilingues dans un cours particulier d'anglais académique (EAP) donné dans le cadre du programme de transition d'une université de l'Est du Canada. Dans une réflexion sur le processus de mise en œuvre, les auteurs identi- 
fient un certain nombre d'arguments clés en faveur de la collaboration entre professeurs et de l'ouverture de l'enseignement de l'anglais académique au plurilinguisme dans l'enseignement supérieur.

Wernicke se penche sur l'amélioration de la sensibilisation aux approches plurilingues et de leur adoption par les candidats à l'enseignement du français dans le cadre d'un cours obligatoire de formation des enseignants portant sur l'enseignement et l'apprentissage de l'anglais comme langue complémentaire. La discussion décrit diverses composantes du cours afin d'illustrer comment une réflexion personnelle initiale suivie d'une modélisation d'activités en classe centrées sur les genres d'écoles et ancrées dans une approche fonctionnelle peut permettre de perturber les idéologies monoglosses dominantes associées à la politique officielle sur le bilinguisme français-anglais.

\section{Quelques réflexions en terminant}

La naissance de cet effort remonte au début de 2017 lors d'un colloque intitulé Language in the Canadian University (https://lcuweb.wordpress.com/) qui s'est déroulé à l'Université Simon Fraser et à l'Université de la Colombie-Britannique et qui rassemblait pour la première fois des chercheurs, des administrateurs, et des professionnels de 17 établissements canadiens et leur permettaient de partager des idées et des expériences. ${ }^{1}$ Les participants ont alors souligné le besoin de poursuivre les recherches et la réflexion sur les questions relatives aux politiques et aux pratiques de l'enseignement supérieur, et ils ont également manifesté un intérêt pour la consolidation de la base de connaissances et de l'expertise en recherche qui continuent de se développer au Canada dans le domaine de l'enseignement et de l'apprentissage des langues au niveau supérieur. Le présent numéro spécial s'inspire de cette démarche collaborative et en est le résultat direct.

Consacré à la théorie, à la recherche, et à la pratique, ce numéro spécial mobilise les connaissances des approches éducatives en soutien de l'enseignement et de l'apprentissage des langues dans le contexte universitaire multilingue et multiculturel. Nous verrons plus tard si ces travaux seront repris et dans quelle mesure ils seront développés, et les recherches à venir nous en apprendront davantage à ce sujet. Par ailleurs, nous avons reçu plus d'articles que nous ne pouvions en publier dans le présent numéro, ce qui veut dire que nous pouvons espérer que ce que nous avons rassemblé ici n'est que le point de départ d'une mobilisation, d'un échange, et d'une diffusion de perspectives et d'approches concernant l'étude des langues dans le contexte universitaire. Nous avons pu constater que de tels travaux sont en cours à travers le Canada, ce qui laisse entrevoir l'émergence d'une base de connaissances et d'expertise qui, même si elle s'inspire de travaux effectués ailleurs, n'en constitue pas moins un engagement et une contribution du Canada dans les domaines interdisciplinaires de l'enseignement des langues. 
Il reste encore des écarts à combler, comme le démontrait notre appel d'articles initial, qui faisait état d'une recherche de textes consacrés à l'enseignement de l'anglais, mais également à l'apprentissage et à l'enseignement des langues patrimoniales et modernes dans des contextes postsecondaires. Qui plus est, comme rédactrices d'un numéro spécial dans un contexte canadien de réconciliation, les travaux sur cette question nous ont sensibilisées à la nécessité de ne pas nous contenter d'articles individuels, mais d'envisager de plus amples conversations et de contributions qui se font attendre depuis longtemps dans notre domaine. La préparation de ce numéro nous a permis de faire avancer un peu plus notre compréhension grandissante des savoirs autochtones et de la façon dont ils sont produits, lus, et représentés, ce qui met en évidence les défis de l'inclusion systémique et de la visibilité constante des langues autochtones et de la revitalisation des langues autochtones dans le domaine de la linguistique appliquée au Canada.

Globalement, cet ensemble de travaux en émergence laisse entrevoir la possibilité de publier au moins un autre numéro spécial, et peut-être même de voir un journal canadien existant consacrer spécifiquement une de ses sections au contexte de l'enseignement supérieur. Pareillement, cette expertise pourrait présenter un intérêt pour les programmes de certificat en enseignement de l'anglais langue seconde (TESL) et d'enseignement de l'anglais aux locuteurs d'autres langues (TESOL), et plus généralement pour la formation des professeurs en offrant un soutien aux candidats à l'enseignement et aux futurs professeurs de langue en formation, et ce, en plus de représenter un apprentissage professionnel fait sur mesure pour les contextes postsecondaires.

Saskia Van Viegen (Université York) Meike Wernicke (Université de la Colombie-Britannique) Sandra Zappa-Hollman (Université de la Colombie-Britannique)

\section{Note}

1. Le colloque intitulé Language in the Canadian University (LCU) a été financé en grande partie grâce à une subvention multi-institutionnelle accordée au groupe de travail de LCU par le programme Connexion du Conseil de recherches en sciences humaines (CRSH).

\section{Remerciements}

Nous tenons à exprimer notre appréciation aux rédactrices de La Revue TESL du Canada, Farahnaz Faez et Antonella Valeo, pour avoir accueilli le présent numéro spécial ainsi que pour leurs conseils et leur aide. Nous remercions également tous les auteurs, les réviseurs anonymes et l'adjoint à la rédaction Michael Karas pour leurs précieuses contributions, ainsi que tous ceux et celles qui ont soumis des manuscrits pour examen. 